OPEN

SUBJECT AREAS:

CLIMATE-CHANGE

ECOLOGY

TROPICAL ECOLOGY

ENVIRONMENTAL SCIENCES

STABLE ISOTOPES

Received

15 May 2013

Accepted

12 September 2013

Published

30 September 2013

Correspondence and requests for materials should be addressed to L.S. (slg@ustc.edu.cn)

* These authors contributed equally to this work.

\section{Penguin tissue as a proxy for relative krill abundance in East Antarctica during the Holocene}

\author{
Tao Huang*, Liguang Sun*, Nanye Long, Yuhong Wang \& Wen Huang
}

Institute of Polar Environment, School of Earth and Space Sciences, University of Science and Technology of China, Hefei 230026, Anhui, China.

Antarctic krill (Euphausia superba) is a key component of the Southern Ocean food web. It supports a large number of upper trophic-level predators, and is also a major fishery resource. Understanding changes in krill abundance has long been a priority for research and conservation in the Southern Ocean. In this study, we performed stable isotope analyses on ancient Adélie penguin tissues and inferred relative krill abundance during the Holocene epoch from paleodiets of Adélie penguin (Pygoscelis adeliae), using inverse of $\delta^{15} \mathrm{~N}$ (ratio of ${ }^{15} \mathrm{~N} /{ }^{14} \mathrm{~N}$ ) value as a proxy. We find that variations in krill abundance during the Holocene are in accord with episodes of regional climate changes, showing greater krill abundance in cold periods.

Moreover, the low $\delta^{15} \mathrm{~N}$ values found in modern Adélie penguins indicate relatively high krill availability, which supports the hypothesis of krill surplus in modern ages due to recent hunt for krill-eating seals and whales by humans.

T

he Southern Ocean is biologically the world's most productive ocean. At the hub of the Antarctic marine food web, krill is the primary consumer of diatoms, the major prey for many species of fishes, penguins, seals and whales ${ }^{1-3}$, and a substantial commercial fishery resource ${ }^{1}$. The abundance of krill is very sensitive to climate change and has significant impacts on high trophic-level predators in the Southern Ocean ecosystems $\mathrm{s}^{4,5}$. Recent Antarctic krill populations have been significantly influenced by rapid climate change, human removal of krill-eating predators and intense commercial fishing ${ }^{1,6,7}$. Therefore, the records of krill population change, especially those pre-dating the onset of human harvesting in Antarctic, are crucial for understanding and predicting responses of krill population to natural climate changes.

Modern krill abundance can be obtained directly from acoustic and net surveys. Krill population data from scientific trawls are available for the past $\sim 30$ years $^{6}$. For historical krill abundance, only about 100 years of data have been inferred from Antarctic fur seals ${ }^{8}$. The long-term historical krill abundance prior to human intervenes remains unknown. Similar to Antarctic fur seal, Adélie penguin is an important land-based krill predator, which has been chosen as an indicator of changes in krill availability and abundance by the commission for the conservation of Antarctic marine living resources?. Furthermore, Adélie penguin is a circum-Antarctic distributed species; continuous and long time-series remains of Adélie penguin could be preserved in various lake sediments ${ }^{10}$. Thus, Adélie penguin is an ideal indicator for tracking krill availability and abundance over a long period of time.

Stable isotope analysis of animal tissues is a powerful tool for examining wildlife foraging habitats, diet and migration patterns $s^{11-13}$, especially in historical periods ${ }^{14,15}$. Keratinous tissues such as toe nails, feathers and hair, and bone collagen can preserve dietary information for long periods of time ${ }^{16}$, particularly in the cold and dry Antarctic environment. They are ideal for investigating paleodiets of krill predators ${ }^{8}$. Hairs and faeces in lake sediments have been used successfully to infer past population dynamics of seals and penguins in Antarctica ${ }^{17-19}$. Similar stable isotopes and biomarkers have also been used extensively in northern high-latitude or Arctic regions to study the effects of climate change, seabird colonisation and past whaling activities on lake ecosystems $\mathrm{s}^{20-22}$.

Here, we analyzed stable nitrogen isotope ratios $\left({ }^{15} \mathrm{~N} /{ }^{14} \mathrm{~N}\right.$, expressed as $\left.\delta^{15} \mathrm{~N}\right)$ of modern and ancient Adélie penguin bones and feathers from the Vestfold Hills, East Antarctica (Figure $1^{23,24}$ and Figure $2^{25}$ ), with the main aim of inferring the relative krill abundance over a long historical time. Several observations follow. First, $\delta^{15} \mathrm{~N}$ values in penguin tissues show an enrichment of $\sim 3-5 \%$ from prey to predator in marine ecosystems ${ }^{11}$. Second, as a diet of penguins, krill are much lower in $\delta^{15} \mathrm{~N}$ values than fishes are ${ }^{15}$. Third, Adélie penguins feed preferentially on krill species ${ }^{26-28}$ of Euphausia superba in the Antarctic Peninsula and of Euphausia crystallorophias along 


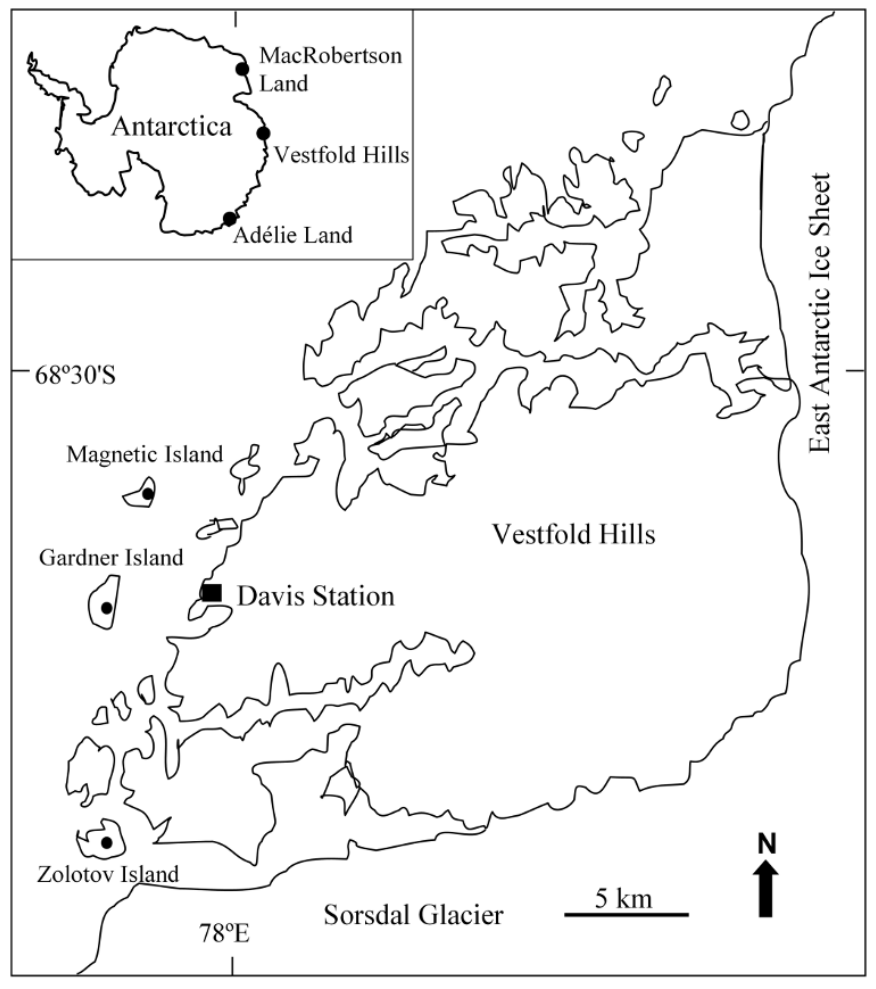

Figure $1 \mid$ Map of the Vestfold Hills including the sampling site in this study and two sites in previous studies ${ }^{23,24}$ in East Antarctica. (The map was drawn using Microsoft Excel 2010 and then converted to tiff format using Microsoft Office Visio 2007).

the East Antarctic coasts. Lower $\delta^{15} \mathrm{~N}$ values in Adélie penguins indicate diets based primarily on krill, while higher values indicate diets richer in fishes and other species of potentially higher trophic level (e.g., squid). The variations in $\delta^{15} \mathrm{~N}$ values of penguin tissues indicate the changes in the proportion of krill in penguin diets and thus the krill availability and abundance in the foraging area ${ }^{29}$. The $\delta^{15} \mathrm{~N}$ values in penguin tissues through time could serve as a proxy for krill availability and abundance in foraging areas.

\section{Results}

The $\delta^{15} \mathrm{~N}$ values of penguin bones and feathers at different depths of a sediment core DG4, as well as modern samples from Magnetic, Zolotov, and Gardner Island at Vestfold Hills, are given in Table 1. The $\delta^{15} \mathrm{~N}$ values of main preys for Adélie penguin in East Antarctic ${ }^{30,31}$ are plotted in Figure 3. Sample sizes $(n)$ reported below are the numbers of the distinct depths in the DG4 sediment at which samples were collected, as shown in Table 1. Modern Adélie penguins at Vestfold Hills have $\delta^{15} \mathrm{~N}$ value (mean \pm standard error of mean) of $10.1 \pm 0.3 \%$ for bones $(n=6)$ and $10.0 \pm 0.04 \%$ for feathers $(n=6)$, which are very close to those reported in Adélie Land (9.4 $\pm 0.09 \%, n=20)$ and MacRobertson Land $(9.4 \pm 0.2 \%, n$ $=31$ ), East Antarctica ${ }^{23,24}$ (Figure 3). The $\delta^{15} \mathrm{~N}$ values of ancient Adélie penguins are much higher. They ranged from $12.5 \%$ to $18.1 \%$ in the bones with a mean of $15.3 \pm 0.6 \%(n=10)$, and ranged from $11.3 \%$ to $15.5 \%$ with a mean of $13.6 \pm 0.4 \%$ o $(n=$ 11 ) in the feathers (Table 1 and Figure 4).

The $\delta^{15} \mathrm{~N}$ values in modern Adélie penguin bones and feathers at Vestfold Hills are similar (Wilcoxon rank sum test statistic $T=45, p$ $=0.35$ ). For the same type of tissues, $\delta^{15} \mathrm{~N}$ in modern and ancient samples are significantly different (for bones: $T=115, p=0.0002$, and for feathers: $T=132, p=0.0002$ ), with higher $\delta^{15} \mathrm{~N}$ found in ancient penguins.

In addition, the $\delta^{15} \mathrm{~N}$ values in ancient penguin feathers and bones between warm and cold climate conditions are also significantly different. Here, we determined the episodic warm periods (7500$6300 \mathrm{yr}$ BP and 4800-2200 yr BP) and cold periods (8500-7600 yr $\mathrm{BP}$ and 6300-5700 yr BP) according to previously reconstructed climate change during the Holocene in East Antarctic based on ice cores $^{32}$ and marine sediment cores ${ }^{33,34}$. Using information of warm/ cold periods provided in Table 1 , we were able to compare $\delta^{15} \mathrm{~N}$

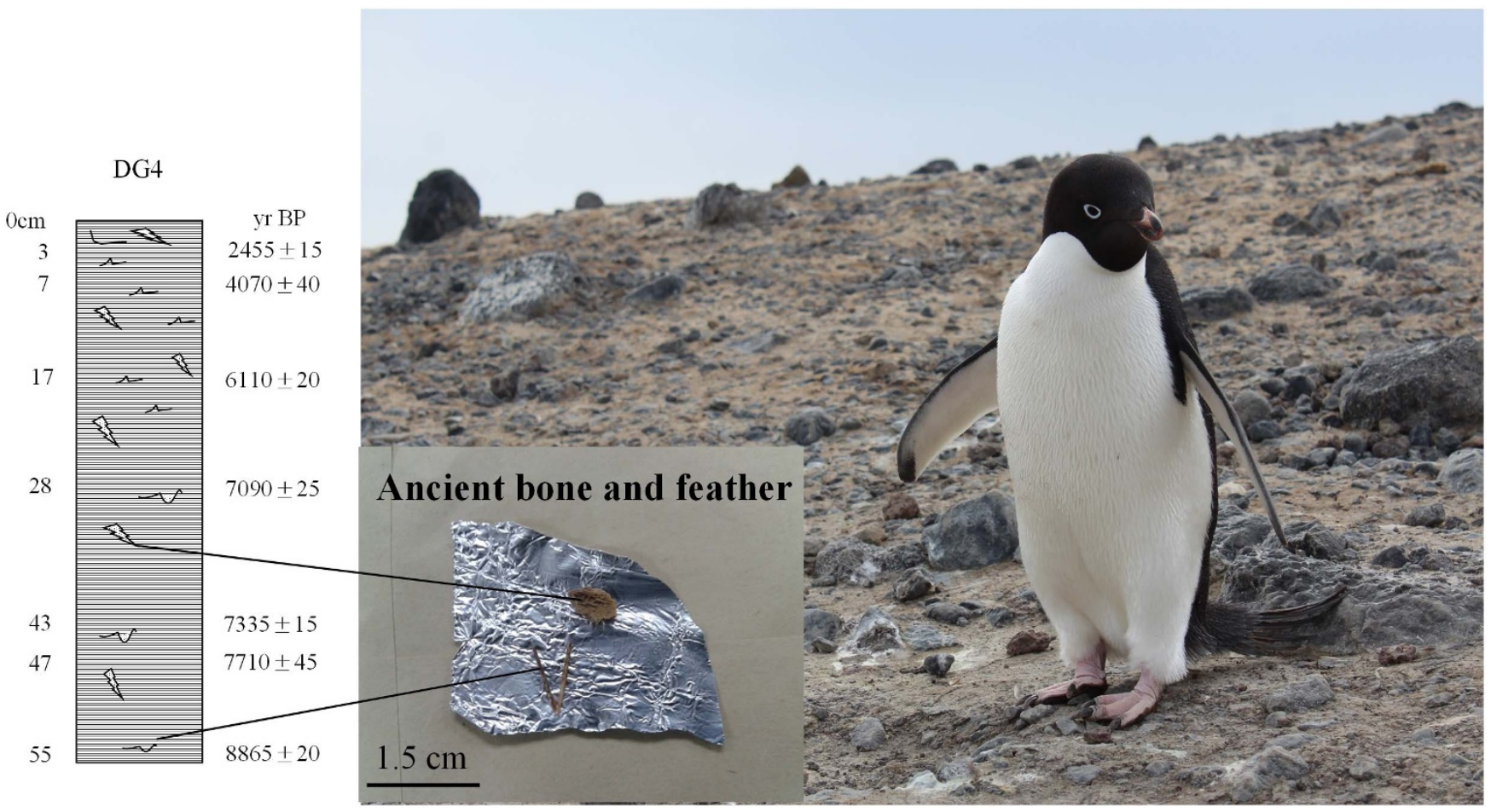

Figure $2 \mid$ Adélie penguin in the Vestfold Hills and the bones and feathers from the sediment core DG4 profile with conventional AMS ${ }^{14} \mathrm{C}$ dates ${ }^{25}$ (yr BP: years before present). Photo credit: T. Huang. 
Table 1 | Stable nitrogen isotope ratios (expressed as $\delta^{15} \mathrm{~N}$ ) of modern and ancient penguin tissues collected from Vestfold Hills, East Antarctica. The interpolated radiocarbon age of ancient penguin tissues were calculated based on $\mathrm{AMS}^{14} \mathrm{C}$ data from a previous study ${ }^{25}$. Also indicated are reconstructed warm/cold climate periods ${ }^{32-34}$ to which the sample at each depth corresponds (slash $=$ neither warm nor cold)

\begin{tabular}{|c|c|c|c|c|c|c|c|c|c|}
\hline $\begin{array}{l}\text { Tissue } \\
\text { (No.) }\end{array}$ & $\begin{array}{l}\text { Depth } \\
\text { (cm) }\end{array}$ & $\begin{array}{c}\text { Age } \\
\text { (yr BP) }\end{array}$ & $\begin{array}{c}\delta^{15} \mathrm{~N} \\
(\% 0)\end{array}$ & $\begin{array}{c}\text { Climate } \\
\text { condition }\end{array}$ & $\begin{array}{l}\text { Tissue } \\
\text { (No.) }\end{array}$ & $\begin{array}{l}\text { Depth } \\
(\mathrm{cm})\end{array}$ & $\begin{array}{c}\text { Age } \\
\text { (yr BP) }\end{array}$ & $\begin{array}{c}\delta^{15} \mathrm{~N} \\
(\% 0)\end{array}$ & $\begin{array}{l}\text { Climate } \\
\text { condition }\end{array}$ \\
\hline Feather* (1) & - & Modern & 10.0 & & Bone* (1) & - & Modern & 8.7 & \\
\hline Feather* (1) & - & Modern & 9.9 & & Bone* (1) & - & Modern & 10.7 & \\
\hline Feather $^{\#}(1)$ & - & Modern & 9.9 & & Bone $^{\#}(1)$ & - & Modern & 10.8 & \\
\hline Feather $^{\#}$ (1) & - & Modern & 10.0 & & Bone $^{\#}(1)$ & - & Modern & 10.7 & \\
\hline Feather $^{\Phi}(1)$ & - & Modern & 10.0 & & Bone $^{\Phi}(1)$ & - & Modern & 10.3 & \\
\hline Feather $^{\Phi}(1)$ & - & Modern & 10.1 & & Bone $^{\Phi}(1)$ & - & Modern & 9.6 & \\
\hline Feather (2) & 12 & 4617 & 14.9 & warm & Bone (1) & 6 & 2756 & 18.1 & warm \\
\hline Feather (1) & 16 & 5453 & 13.6 & / & Bone (1) & 9 & 3786 & 17.3 & warm \\
\hline Feather (2) & 20 & 6030 & 12.2 & cold & Bone (2) & 11 & 4361 & 15.1 & warm \\
\hline Feather (2) & 23 & 6325 & 12.7 & cold & Bone (1) & 14 & 5071 & 13.9 & / \\
\hline Feather (1) & 26 & 6530 & 14.4 & warm & Bone (2) & 21 & 6140 & 12.5 & cold \\
\hline Feather (1) & 27 & 6581 & 15.5 & warm & Bone (2) & 22 & 6238 & 12.7 & cold \\
\hline Feather (1) & 34 & 6805 & 14.9 & warm & Bone (1) & 30 & 6700 & 16.3 & warm \\
\hline Feather (2) & 37 & 6874 & 14.0 & warm & Bone (2) & 36 & 6850 & 15.7 & warm \\
\hline Feather (1) & 41 & 6998 & 13.8 & warm & Bone (1) & 39 & 6929 & 15.3 & warm \\
\hline Feather (1) & 47 & 7725 & 11.3 & cold & Bone (1) & 40 & 6961 & 16.3 & warm \\
\hline Feather (1) & 50 & 8015 & 12.8 & cold & & & & & \\
\hline \multicolumn{10}{|c|}{$\begin{array}{l}\text { Note: } \\
\text { "Magnetic Island, } \\
\text { "Zolotov Island, } \\
\text { *Gardner Island, all ancient feathers and bones were sorted from each 1-cm section of the DG4 sediment core from Gardner Island, and the bones or feathers at the depths where two subsamples were } \\
\text { present were mixed. }\end{array}$} \\
\hline
\end{tabular}

values in cold periods against those in warm periods. It was found that $\delta^{15} \mathrm{~N}$ values of ancient Adélie penguin during cold periods are much lower than those during warm periods (Figure 4), in both bones $\left(T=3, p=0.05, n_{\text {warm }}=7, n_{\text {cold }}=2\right)$ and feathers $(T=$ $\left.10, p=0.01, n_{\text {warm }}=6, n_{\text {cold }}=4\right)$. Furthermore, when combining data from bones and feathers to form a single test, we observed even stronger evidence $(T=21, p=0.0001$, from a tissue-stratified Wilcoxon rank sum test). This implies the relative krill abundance in the cold periods is much higher as compared with that in the warm periods.

\section{Discussion}

Different penguin tissues have different metabolic rates, and their stable isotope signatures have different time scales, from days for blood plasma to weeks for feathers, and to months of average turnover-time for collagen of bones ${ }^{16}$. Because our samples were collected at a breeding site during a summer season, the stable isotope values of archive feathers in the sediment core DG4 reflect those of the average diets at the time of feather growth. The nitrogen isotope values of penguin bones reflect those of the average diets of Adélie penguins during the last turnover of their bone collagen. Visual inspection

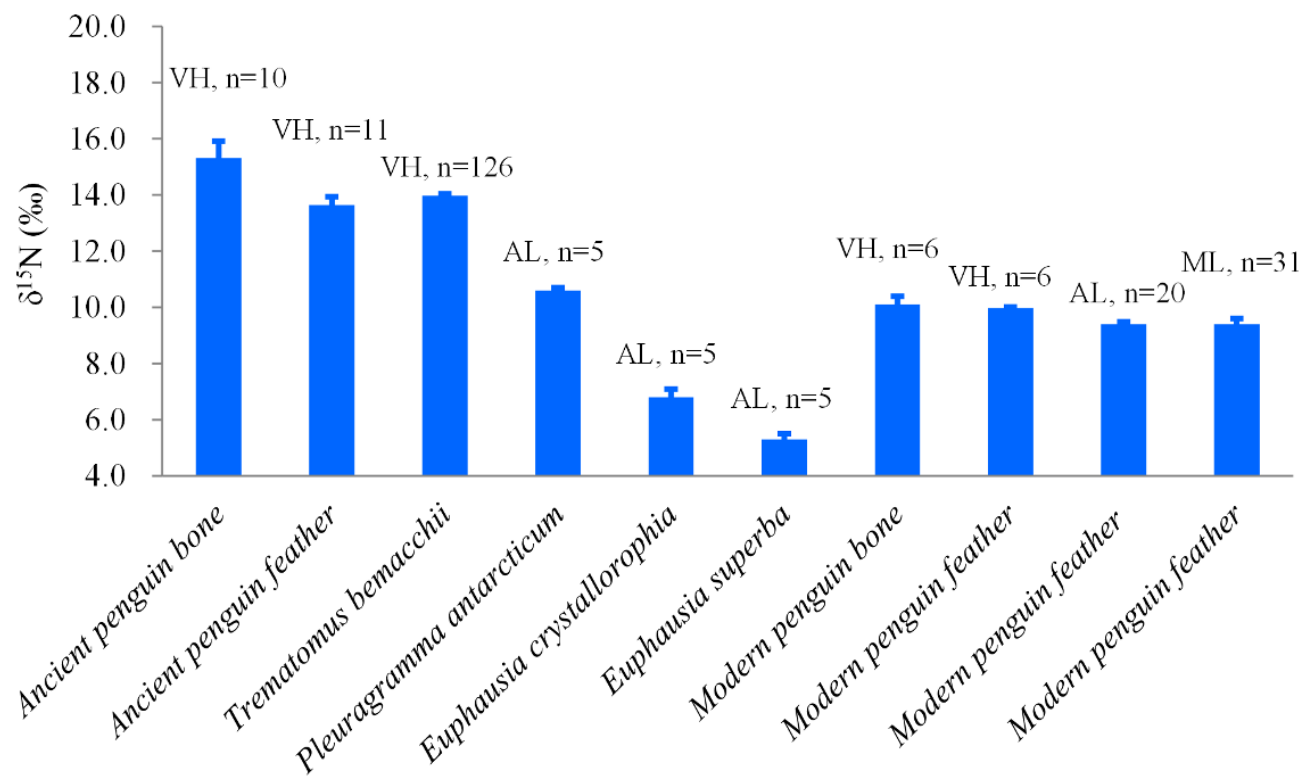

Figure $3 \mid \delta^{15} \mathrm{~N}$ values (mean \pm standard error of mean) of Adélie penguins in this study and previous studies ${ }^{23,24}$, and penguin prey $\delta^{15} \mathrm{~N}$ values compiled by Cherel et al. (2008) ${ }^{30}$ for Euphausia crystallorophias, Euphausia superba and Pleuragramma antarcticum and Gillies et al. (2012) $)^{31}$ for Trematomus bemacchii. (VH: Vestfold Hills, AL: Adélie Land, ML: MacRobertson Land). 


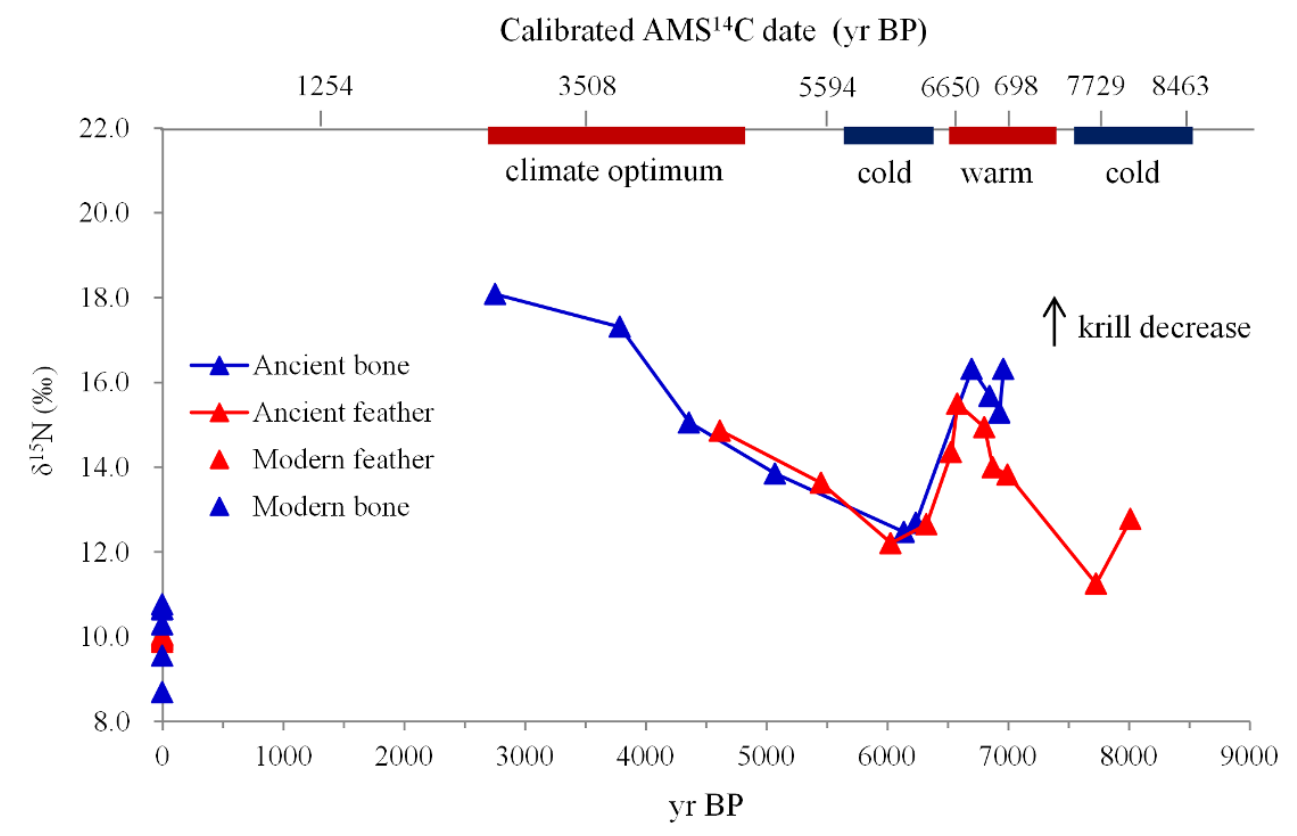

Figure $4 \mid \delta^{15} \mathrm{~N}$ value fluctuations in Adélie penguin bones and feathers during the Holocene epoch, along with the episodes of climate change as inferred from ice cores and marine sediments in East Antarctic ${ }^{32-34}$. The instrument error for the isotope analysis is $\leq 0.2 \%$. Red bands refer to warm climate periods and blue bands to cold periods and expanded sea ice condition.

showed that the ancient feathers in DG4 were from adult penguins whereas the source was uncertain for the bones (which can be from adults and/or juveniles). Since the trend and magnitude of $\delta^{15} \mathrm{~N}$ in the ancient penguin feathers are similar to those in the bones (Figure 4), the possible age difference in the penguin bones seems unlikely to drive the temporal change of $\delta^{15} \mathrm{~N}$ during the Holocene epoch.

Variation of the inferred relative krill abundance (represented by the inverse of $\delta^{15} \mathrm{~N}$ values in penguin tissues) was found to be in accordance with previously reconstructed episodes of climate change during the Holocene in East Antarctic ${ }^{32-34}$. That is, periods with high krill abundance (lower $\delta^{15} \mathrm{~N}$ values) correspond to cold climates ${ }^{32,33}$, whereas periods with low krill abundance (higher $\delta^{15} \mathrm{~N}$ values) correspond to warm climates ${ }^{32,34}$. Krill is a stenothermal, cold-water planktonic species, and is very sensitive to natural climate changes. Krill abundance has been linked with expanded sea ice cover (extent and duration) and increased latitudinal extent of cool water ${ }^{6,35,36}$, which are consistent with our findings. Moreover, our results from Adélie penguins are also consistent with those from Antarctic fur seal hairs from a sediment core spanning the past century in the West Antarctic Peninsula ${ }^{8}$. Taken together, these results suggest that the link between krill abundance and climate persists over the past 8,000 years in East Antarctica.

It has been reported ${ }^{37}$ that $\delta^{15} \mathrm{~N}$ values of the primary producer (baseline) and thus penguins' preys may also be influenced by climates. This can in turn give rise to the change of $\delta^{15} \mathrm{~N}$ in penguins in response to varied climates. However, we note that the $\delta^{15} \mathrm{~N}$ values in the Southern Ocean phytoplankton (fragilariopsis kerguelensis, main food of Antarctic krill) are higher during cold climate periods and lower during warm periods ${ }^{38}$, opposite to the patterns seen in our penguin tissues. Based on these facts, we argue that the temporal variations of $\delta^{15} \mathrm{~N}$ in penguin tissues cannot be attributed to the variation of $\delta^{15} \mathrm{~N}$ of the krill themselves but primarily to the change of penguin's diet composition.

Modern penguin bones and feathers have much lower $\delta^{15} \mathrm{~N}$ values than ancient ones. Similar low $\delta^{15} \mathrm{~N}$ values were also observed in modern penguin eggshells by Emslie \& Patterson $(2007)^{15}$. These differences are most likely caused by substantial dietary changes between modern and ancient Adélie penguins (Figures 3,4). There are two other possibilities which, however, do not seem to explain the differences observed in the current study. First, diagenetic processes may change dietary signals in tissues over time. This is unlikely for penguin feathers and bones because of the excellent preservation condition in the dry and cold Antarctic environment ${ }^{39}$ though the preservation state of ancient tissues has not been directly studied in the present study. Second, ammonia volatilization could cause older tissues to become more enriched in nitrogen-15 than younger or modern tissues ${ }^{40}$. This, however, only applies to sediment, soil and plants growing in the soil. In fact, the ancient penguin bones and feathers in DG4 have much lower $\delta^{15} \mathrm{~N}$ values (12-18\%) than those in the sediments of DG4 core (25-39\%, Table S1) and ornithogenic soils $(\sim 30 \% \text { o) (Mizutani \& Wada, 1988) })^{40}$. Furthermore, this would not explain the similar patterns of fluctuations in $\delta^{15} \mathrm{~N}$ values observed in both feathers and bones if volatilization is a significant factor (see also Emslie et al. $2013^{41}$ ).

Taken together, the lower $\delta^{15} \mathrm{~N}$ values of modern tissues than in ancient tissues indicate higher proportion of krill in modern Adélie penguin diets and thus greater krill abundance in modern ages than in ancient ages, in the East Antarctic. This is consistent with the observations by Emslie \& Patterson $(2007)^{15}$, which supports the 'krill surplus' hypothesis, i.e., the higher krill abundance is likely due to the hunting of krill-eating seals and whales since as early as the $19^{\text {th }}$ century.

One limitation of the present study is the small sample size for analysis. In the sediment core DG4, each $1-\mathrm{cm}$ section contains only one or two pieces of feathers and bones. To address this issue, we have chosen a nonparametric statistical method to test the differences in $\delta^{15} \mathrm{~N}$ values between different conditions. Since Adélie penguins and krill are widely distributed in the circum Antarctic, we expect to find more sampling sites and collect multiple sediments in future field work.

Our results corroborate that climate change has a pronounced effect on krill abundance and hence Adélie penguin diet composition $^{26-28}$. The reported 8000-year record of the relative krill abundance, as inferred from Adélie penguin paleodiets, provides a unique insight into the change of regional marine food chains in natural status. This will be valuable for assessing impacts of future climate changes on this key species and thus for the conservation and management of Antarctic marine resources. 
9. Agnew, D. J. The CCAMLR Ecosystem Monitoring Programme. Antarct. Sci. 9 235-242 (1997).

Sample collection and chronology. We collected a sediment core DG4 near a large Adélie penguin colony at Gardner Island, Vestfold Hills (Figure 1), East Antarctica, during the 2005-2006 austral summer. There are a large number of penguins in the colony in summer breeding seasons, and penguin remains such as guanos, bones and feathers are deposited into the sediments each year (Figure 2). This sediment thus preserves a record of penguin activities at this colony since it was first formed. The core was sectioned at $1 \mathrm{~cm}$ intervals in the lab. Layers from $55 \mathrm{~cm}$ to the surface contained numerous penguin bones and feathers, but sample sizes per $1 \mathrm{~cm}$ section were quite small. Modern bone and feather samples were collected from dead adult penguins at Gardner, Magnetic and Zolotov Island, Vestfold Hills.

The chronology of DG4 has been established by AMS ${ }^{14} \mathrm{C}$ dates on penguin tissues and bulk sediments in the core in a previous study ${ }^{25}$, and the penguin occupation appears to have been continuous since 8500 year BP to the present ${ }^{25}$.

Stable isotope analyses. Penguin bones and feathers were picked from each $1-\mathrm{cm}$ section of the sediment core and used for stable isotope analysis. These samples as well as the modern adult penguin tissues were cleaned with Millipore water and 2:1 chloroform: methanol solution, and then dried in an oven at $40^{\circ} \mathrm{C}$. The cleaned samples were cut into small pieces and weighed in a tin capsule. Stable nitrogen isotope ratios in whole feathers and bone collagens were determined using isotope ratio mass spectrometer at the G.G. Hatch Isotope Laboratories, Earth Sciences, University of Ottawa, with a precision at $\leq 0.2 \%$. Isotope ratio $\left({ }^{15} \mathrm{~N} /{ }^{14} \mathrm{~N}\right)$ in samples are reported in $\delta$ notation, and the units are per mil (\%o) and defined as $\delta^{15} \mathrm{~N}=$ $\left[\left(\mathrm{R}_{\text {sample }}-\mathrm{R}_{\text {standard }}\right) / \mathrm{R}_{\text {standard }}\right]$, where $\mathrm{R}_{\text {sample }}$ is isotope ratio of the sample, and $\mathrm{R}_{\text {standard }}$ of the atmosphere (See Supplementary Information for more detail).

$\delta^{15} \mathrm{~N}$ as a proxy for krill abundance. We used the inverse of isotopic ratio of nitrogen, $\delta^{15} \mathrm{~N}$, in penguin tissues as a qualitative proxy for krill abundance. The $\delta^{15} \mathrm{~N}$ in tissues has been used to reconstruct diet composition of marine species ${ }^{13-15}$. Generally, marine predators are ${ }^{15} \mathrm{~N}$-enriched over their diet, because of the kinetic isotope effects in metabolic pathways involving the bond-breaking or synthesis of biochemical compounds, during which the molecules that contain the lighter nitrogen-14 are preferentially utilized over the same molecules containing the heavier nitrogen- $15^{11} . \delta^{15} \mathrm{~N}$ values can therefore be used as an indicator for the dietary change of marine predators.

Information of krill population can be estimated from penguin's diets based on traditional methods such as stomach lavage analyse ${ }^{42}$ which, however, often come with biases associated with sampling of gut contents. The stable nitrogen isotope method as used here can be regarded as a qualitative biochemical method, and reflects the average amount of all the diets rather than specific ones. Since this method assesses paleodiets of wildlife through their ancient tissues ${ }^{8}$, there is no time limitation regarding availability of diets.

Adélie penguins feed primarily on krill and, when krill are scarce, on fishes ${ }^{26-28}$. Because krill are much more ${ }^{15} \mathrm{~N}$-depleted than fishes ${ }^{15}, \delta^{15} \mathrm{~N}$ in penguin tissues where diet information is well preserved can indicate the changes of the proportion of krill and thus their abundance. Specifically, high $\delta^{15} \mathrm{~N}$ indicates low krill abundance and low $\delta^{15} \mathrm{~N}$ indicates high krill abundance.

Statistical test for differences in $\boldsymbol{\delta}^{\mathbf{1 5}} \mathbf{N}$ between different conditions. To assess the significance of the difference in penguin $\delta^{15} \mathrm{~N}$ isotope values between different time periods (modern $v s$. ancient), different tissues (feather $v s$. bone), and different reconstructed climate conditions (warm $v s$. cold), we adopted the nonparametric Wilcoxon rank sum test. Due to small samples sizes and presence of ties, asymptotic $p$ value resulting from a Normal distribution approximation is invalid. Therefore, we used an exact two-sided $p$ value obtained via a permutation procedure (i.e., randomly reassigning $\delta^{15} \mathrm{~N}$ values across groups of samples) for each test as reported in "Results". The function "wilcox_test" in the R package "coin" was used to perform these tests. The function also implements an extension of the Wilcoxon rank sum test to allow for stratifying on another factor. We've utilized this technique to compare $\delta^{15} \mathrm{~N}$ in cold periods vs. $\delta^{15} \mathrm{~N}$ in warm periods while accounting for the possible impact of tissues (bone or feather) on $\delta^{15} \mathrm{~N}$.

1. Everson, E. Krill. Biology, Ecology and Fisheries (Blackwell Science, London, 2000).

2. Hofmann, E. E. \& Murphy, E. J. Advection, krill, and Antarctic marine ecosystems. Antarct Sci 16, 487-499 (2004).

3. Nicol, S. Krill, Currents, and Sea Ice: Euphausia superba and Its Changing Environment. Bioscience 56, 111-120 (2006).

4. Croxall, J. P. Southern-ocean environmental changes: effects on seabird, seal and whale populations. Phil. Trans. R. Soc. B 338, 319-328 (1992).

5. Trivelpiece, W. Z. et al. Variability in krill biomass links harvesting and climate warming to penguin population changes in Antarctica. Proc. Natl. Acad. Sci. USA 108, 7625-7628 (2011).

6. Atkinson, A., Siegel, V., Pakhomov, E. \& Rothery, P. Long-term decline in krill stock and increase in salps within the Southern Ocean. Nature 432, 100-103 (2004).

7. Nicol, S., Foster, J. \& Kawaguchi, S. The fishery for Antarctic krill-recent developments. Fish. Fish 13, 30-40 (2012).

8. Huang, T. et al. Relative Changes in Krill Abundance Inferred from Antarctic Fur Seal. PLoS ONE 6(11), e27331 (2011).
10. Sun, L. G. et al. Vertebrate records in polar sediments: biological responses to past climate change and human activities. Earth-Sci Rev 126, 147-155 (2013).

11. Hobson, K. A., Piatt, J. F. \& Pitocchelli, J. Using Stable Isotopes to Determine Seabird Trophic Relationships. J. Anim. Ecol. 63, 786-798 (1994).

12. Cerling, T. E. et al. 2006 Stable isotopes in elephant hair document migration patterns and diet changes. Proc. Natl. Acad. Sci. USA 103, 371-373 (2006).

13. Cherel, Y., Kernaleguen, L., Richard, P. \& Guinet, C. Whisker isotopic signature depicts migration patterns and multi-year intra- and inter-individual foraging strategies in fur seals. Biol. Lett. 5, 830-832 (2009).

14. Hilton, G. M. et al. A stable isotopic investigation into the causes of decline in a sub-Antarctic predator, the rockhopper penguin Eudyptes chrysocome. Global Change Biol 12, 611-625 (2006).

15. Emslie, S. D. \& Patterson, W. P. Abrupt recent shift in delta C-13 and delta N-15 values in Adélie penguin eggshell in Antarctica. Proc. Natl. Acad. Sci. USA 104, 11666-11669 (2007).

16. Bearhop, S., Furness, R. W., Hilton, G. H. \& Waldron, S. A forensic approach to understanding diet and habitat use from stable isotope analysis of (avian) claw material. Funct. Ecol. 17, 270-275 (2003).

17. Hodgson, D. A. \& Johnston, N. M. Inferring seal populations from lake sediments. Nature 387, 30-31 (1997)

18. Sun, L. G., Xie, Z. Q. \& Zhao, J. L. Palaeoecology-A 3,000-year record of penguin populations. Nature 407, 858-858 (2000).

19. Sun, L. G. et al. A 1,500-year record of Antarctic seal populations in response to climate change. Polar Biol. 27, 495-501 (2004).

20. Smol, J. P. et al. Climate-driven regime shifts in the biological communities of Arctic lakes. Proc. Natl Acad. Sci. USA 102, 4397-4402 (2005).

21. Michelutti, N. et al. Seabird-driven shifts in Arctic pond ecosystems. Proc. R. Soc. B 276, 591-596 (2009).

22. Douglas, M. S. V., Smol, J. P., Savelle, J. M. \& Blais, J. M. Prehistoric Inuit whalers affected Arctic freshwater ecosystems. Proc. Natl. Acad. Sci. USA 101, 1613-1617 (2004).

23. Jaeger, A. \& Cherel, Y. Isotopic Investigation of Contemporary and Historic Changes in Penguin Trophic Niches and Carrying Capacity of the Southern Indian Ocean. PLoS ONE 6, e16484 (2011).

24. Tierney, M., Southwell, C., Emmerson, L. M. \& Hindell, M. A. Evaluating and using stable-isotope analysis to infer diet composition and foraging ecology of Adélie penguins Pygoscelis adeliae. Mar Eco Prog Ser 355, 297-307 (2008).

25. Huang, T. et al. Penguin population dynamics for the past 8500 years at Gardner Island, Vestfold Hills. Antarct Sci 21, 571-578 (2009).

26. Ainley, D. G. et al. Spatial and temporal variation of diet within a presumed metapopulation of Adélie Penguins. Condor 105, 95-106 (2003).

27. Murphy, E. J. et al. Spatial and temporal operation of the Scotia Sea ecosystem: a review of large-scale links in a krill centred food web. Phil. Trans. R. Soc. B 362, 113-148 (2007).

28. Nicol, S. et al. Krill (Euphausia superba) abundance and Adélie penguin (Pygoscelis adeliae) breeding performance in the waters off the Béchervaise Island colony, East Antarctica in two years with contrasting ecological conditions. Deep Sea Res Part II 55, 540-557 (2008).

29. Polito, M. J. et al. Integrating Stomach Content and Stable Isotope Analyses to Quantify the Diets of Pygoscelid Penguins. PLoS ONE 6(10), e26642 (2011).

30. Cherel, Y. Isotopic niches of emperor and Adélie penguins in Adélie Land, Antarctica. Mar. Biol. 154, 813-821 (2008).

31. Gillies, C. L., Stark, J. S. \& Smith, S. D. A. Research article: small-scale spatial variation of $\delta 13 \mathrm{C}$ and $\delta 15 \mathrm{~N}$ isotopes in Antarctic carbon sources and consumers Polar Biol. 35, 813-827 (2012).

32. Masson, V. et al. Holocene Climate Variability in Antarctica Based on 11 Ice-Core Isotopic Records. Quatern. Res. 54, 348-358 (2000).

33. Denis, D. et al. Holocene productivity changes off Adélie Land (East Antarctica) Paleoceanography 24, PA3207 (2009).

34. McMinn, A., Heijnis, H., Harle, K. \& McOrist, G. Late-Holocene climatic change recorded in sediment cores from Ellis Fjord, eastern Antarctica. Holocene 11, 291-300 (2001)

35. Loeb, V. et al. Effects of sea-ice extent and krill or salp dominance on the Antarctic food web. Nature 387, 897-900 (1997).

36. Nicol, S. et al. Ocean circulation off east Antarctica affects ecosystem structure and sea-ice extent. Nature 406, 504-507 (2000).

37. Rau, G. H., Ohman, M. D. \& Pierrot-Bults, A. Linking nitrogen dynamics to climate variability off central California: a 51 year record based on $15 \mathrm{~N} / 14 \mathrm{~N}$ in CalCOFI zooplankton. Deep-Sea Res Part II 40, 2431-2447 (2003)

38. Crosta, X. \& Shemesh, A. Reconciling down core anticorrelation of diatom carbon and nitrogen isotopic ratios from the Southern Ocean. Paleoceanography 17, 1010 (2002).

39. Emslie, S. D., Coats, L. \& Licht, K. A 45,000 yr record of Adélie penguins and climate change in the Ross Sea, Antarctica. Geology 35, 61-64 (2007b).

40. Mizutani H, W. E. Nitrogen and Carbon Isotope Ratios in Seabird Rookeries and their Ecological Implications. Ecology 69, 340-349 (1988).

41. Emslie, S. D., Polito, M. J. \& Patterson, W. P. Stable isotope analysis of ancient and modern Gentoo Penguin egg membrane supports the krill surplus hypothesis in Antarctica. Antarct Sci 25, 213-218 (2013). 
42. Reid, K., Watkins, J. L., Croxall, J. P. \& Murphy, E. J. Krill population dynamics at South Georgia 1991-1997, based on data from predators and nets. Mar Ecol Prog Ser 177, 103-114 (1999).

\section{Acknowledgements}

The authors are grateful to the Chinese Arctic and Antarctic Administration and Australian Antarctic Division for logistical support in the field work. This study was funded by NSFC (No. 40730107, 41106162), Chinese Polar Environment Comprehensive Investigation \& Assessment Programmes (CHINARE2013-04-04-09, CHINARE2013-02-01-03) and the Fundamental Research Funds for Central Universities. Samples in this study were provided by the BIRDS-Sediment system. We thank two anonymous reviewers for critical comments and suggestions on an earlier version of the manuscript. Dr. Steve Emslie (University of North Carolina at Wilmington) provided insightful comments and also helped to polish the language.

\section{Author contributions}

L.S. and T.H. conceived and designed the study. T.H. performed the experiments, N.L. performed the statistical analysis. L.S., T.H., Y.W., W.H. and N.L. analyzed the data and wrote the paper.

\section{Additional information}

Supplementary information accompanies this paper at http://www.nature.com/ scientificreports

Competing financial interests: The authors declare no competing financial interests.

How to cite this article: Huang, T., Sun, L., Long, N., Wang, Y. \& Huang, W. Penguin tissue as a proxy for relative krill abundance in East Antarctica during the Holocene. Sci. Rep. 3, 2807; DOI:10.1038/srep02807 (2013).

cc) (i) $(-)$ This work is licensed under a Creative Commons AttributionBy No NonCommercial-NoDerivs 3.0 Unported license. To view a copy of this license, visit http://creativecommons.org/licenses/by-nc-nd/3.0 